\title{
Cosearch Square \\ An Approach To Cultural Competency Education in The Cuban Pharmacy Currriculum
}

Alina de las Mercedes Martínez Sánchez ( $\nabla$ alimarti2014@gmail.com )

Autonomous University of Madrid

Jack Warrent Salmon

University of Illinois at Chicago

Research Article

Keywords: cultural competency, assessment, curriculum, pharmacy education, Cuba

Posted Date: November 15th, 2021

DOl: https://doi.org/10.21203/rs.3.rs-1039757/v1

License: (a) (i) This work is licensed under a Creative Commons Attribution 4.0 International License. Read Full License 


\section{Abstract \\ Background}

The aim of this monograph was advocate for a holistic, programmatic approach to integrating cultural competence education as a call to action for a new Cuban pharmacy curricular development.

\section{Methods}

A general search was conducted using terms specific to Cuban health care, culture, and education, combined with terms linked to cultural competence, global health, and pharmacy education. Additionally, relevant statements by the Pan American Health Organization and World Health Organization were searched.

\section{Results}

Cuba is a culturally rich country with complex and diverse perspectives on health. Cuban culture is the result of extremely broad and tedious transculturation processes; at the same time, health and education in Cuba are additionally entwined politically, a condition not always statistically available to be studied, nor scientifically referenced to be verified. Therefore, it is not possible to exhaust the subject in a single inquiry.

\section{Conclusions}

It is hoped that this paper will also set the foundation for additional scholarly work with recommendations regarding a clearer programmatic approach to help in the establishment of partnerships between Cuba faculties of pharmacy with other countries in a global pharmacy education framework.

\section{Introduction}

Over the past several years, the responsibility of pharmacists' in health care systems has been underlined by the World Health Organization (WHO) and the International Pharmaceutical Federation (FIP) [1-4]. Pharmacy practice is changing. away from merely dispensing drugs towards patient-centered care. According to the challenges facing pharmacists, there is a critical need to prepare these professionals to advance their services to become truly patient-centered. Beyond knowledge and skills, educational curricula must reflect the wide range of competences that forthcoming pharmacists will deliver in national health systems.

This transition toward patient-centered pharmacy services began in certain developed countries because of healthsystem planning and capital spending in academic and practice training, and for promoting quality assurance [5]. Developed countries stand at the forefront in competency-based pharmacy curricula, while, in developing countries, shortcomings in pharmacy education continue to be an obstacle for the pharmacy patient-centered care [6].

Even though having vast knowledge on new medicines-which are increasingly more powerful and dangerous--the challenge to design and implement curricula to produce pharmacists capable of providing newer novel services to better manage complex pharmacotherapy [7]. So, the dispensing model tends to remain dominant despite patient 
care and health systems requiring significant upgrading of pharmaceutical care to meett crucial health needs remains a question in some developing countries. In addition, pharmacy curricular have incorporated social pharmacy topics to provide students with more opportunities to engage with their populations [8].

This transformation has been conducted in some developing countries like Cuba; subjects related to drug information, patient counselling, drug-related problems, and compliance are analyzed offering a wide opportunity to pharmacy practice. Nevertheless, there is no documented scientific evidence about the contribution of these courses to yield a culturally competent pharmacist to become an active health care manager. In line with Olsen [9], pharmacy curricula must introduce innovative models to ensure students are trained for the evolving world of health care, highlight cultural competency and cultural humility and to encourage inter- and intra-professional sensitivities.

This article advocates a holistic, programmatic approach to integrating cultural competence education and serves as a call to action for a Cuban pharmacy curricular development. It is hoped that this paper will also set the foundation for additional scholarly work and recommendations regarding a programmatic approach. Similarly, this paper could be useful to help to establish partnerships between Cuba faculties of pharmacy and other countries in a new global pharmacy education framework.

\section{Cultural Competence In The Cuban Pharmacy Curriculum}

A definitive clarity for cultural competence remains difficult since it is a constantly changing process: similarly, the concept has evolved from diverse perceptions, pursuits, and requirements. However, there are some practical working definitions, for instance, Davis [10] defines the term like "a journey and a pathway towards becoming competent in working with, and between, diverse cultural situations and contexts." At the same time, the scientific literature recognizes the consistent foundation showed by Cross et al. [11] as a basic and universally framework interrelated through several systems. This author stated the term 'cultural competence' signifies a set of congruent behaviors, attitudes, and policies that come together in a system, agency or among professionals to enable that system, agency, or those professions to work effectively in cross-cultural situations.

For the purpose of our article, a definition by Shaya was adopted, considering cultural competence as "a student's ability in the health professions to deliver culturally appropriate and specifically tailored care to patient populations with diverse values, beliefs, and behaviours"[12]. Breaking down this definition means focusing on two essential concepts: culture and competence. Both have a great impact on education in general and on the training of health professionals. Culture involves the combined patterns of human behaviour, including among others, beliefs, values, and communication. On the other hand, competence defines the applied abilities and knowledge that enable persons to effectively act in professional, educational, and other life contexts. The competence concept generated a movement in the theory and practice of curriculum discipline in the United States in 1960s \& 1970s and then proliferated internationally. On the other hand, the model of the competence-based curriculum turned into one of the most discussed topics among experts in the education sciences and by curriculum stakeholders [13].

An interesting point of view on competence is its relatedness to understanding it as a connection among the work market with the results of the educational systems $[14,15]$. In line with the Future of Education and Skills 2030, the main scheme to redesign the curriculum is its suggestion of instilling core competencies. Enlisting the global

tendencies of competencies in education, for instance, was applied by the Organization for Economic Co-operation 
and Development [16]. The challenge is to produce citizens capable to face a world market undoubtedly undetermined.

Pedagogical needs stemming from multiculturalism requests require not only methodological and content knowledge, but also development of awareness of who we are, where we come from and what our new roles in this world should be. Thus, thinking of Paulo Freire's contributions of culture, different, ethics, sensitivity, diversity, inclusion, reflection-action, should become foundational with respect and knowledge of people's culture so that they become able to educate themselves [17].

In Cuba, pharmacy centered-patient care was presented in the practice and education law from the Cuban government in 2005. Currently, a new pharmacy curriculum was approved by the Cuban Council on Higher Education, consisting of pharmacy centered-patient care to be considered as an eligible matter into the outline of a self-obligatory basic curricula in accordance with the requirements linked to the social and geographical setting university [18]. However, limited published evidence is accessible on pharmacy centered-patient care education and practice, in both, Cuban Pharmacy Education and health system.

On the other hand, Cuba shows progress in a competency-based training model, with emphasis placed on incorporating ethics and values as elements of competent performance. It has been decided to implement competency-based training in technical and vocational education, after assessing the general results of the accumulated experience. In addition, competency-based training models have been established in different educational institutions, being worked on in Cuban Higher Education, within different careers and centers, although studies carried out in the field of Physical Culture and Physical Education are limited. All developmental models are based on the Historical-cultural foundation [19].

\subsection{Cultural Competency Education and Pharmacy}

Cultural competence has emerged as one more solution to ease a variety of disparities in healthcare. Healthcare is a cultural construct therefore, beliefs about the health, illness, drug treatment and delivery of healthcare services will be essential in patient-centered care. Also, health is determined by several factors outside the conventional healthcare setting. These social factors of health include, but are not restricted to, education, housing quality, and access to healthy diets [20]. To produce healthcare professionals capable to provide their services respecting patient's culture, competences \& recognizing human diversity, must be a guaranty by the educational institutions. Humans being biopsychosocial diverse in nature affords multiculturalism to bring new challenge for healthcare providers around the world [21, 22]. Thus, International Federation of Medical Students' Associations (IFMSA) believes that "developing and incorporating cultural competence in health professions education (medical, dentistry, nursing, pharmaceutical, paramedics, veterinary \& social sciences students) is the key to the development of a culturally competent health workforce, who will be able to adapt and deliver in a culturally diverse environment" [23]. Furthermore, cultural competence is a crucial for better health outcomes.

The importance of cultural competence training has been considered in several pharmacy education statements as part of the Pharmacists' Patient Care Process [24, 25]. Nevertheless, there is significant discrepancy in implementation of cultural competence on a curriculum, due to there is no consensus on how this could be implemented from a point of view logical and pedagogical coherent [26]. Consequently, a cultural and interdisciplinary approach should be considered in the curriculum design process respecting the laws and pedagogical principles that guide the process of training professionals at the universities and pharmacy schools.

Page $4 / 19$ 
For the time being, cultural competence continuing being an absent or not be adequately taught topic in several pharmacy schools from the United State and other countries [27].

Several studies suggest the benefits of cultural competence in pharmacy practice and education [28-31]. Consequently, pharmacy should assume diversity to deliver excellent care to all patients, even knowing that pharmacists may lack basic education in cultural competence [32]. While many pharmacists have shown a positive attitude to face the new professional challenges, research by Haack [33]. developed and implemented an advanced pharmacy practice experience to increase students' cultural competence. This author found: $98 \%$ learned something new about counseling patients with cultural/language differences; $93 \%$ increased their awareness about financial barriers to care and its potential solutions. Accordingly, immersion into a culturally diverse patient population presents opportunities for pharmacy students to improve their cultural competence. Minshew et al. [34]. created a cultural intelligence framework to help prepare future pharmacists to be socially responsible health care providers. Four domains (Awareness, Knowledge, Practice, Desire) were observed, in addition, the Cultural Practice domain was a topic discussed by students where different experiences were described by the students regarding year in the curriculum and race.

Cuba, being internationally recognized for its health professionals' quality [35]. Makes an approach to cultural competence education imperative as a next step for the pharmacy curriculum. As reported by Abrons et al. [36] and Haack et al. [37], pharmacists and medical professionals from Dominica and Jamaica are educated in Cuba. Likewise, difficulties in pharmacy practices and regulation in these countries are supplied with Cuba contractual arrangements. According to Gorry [38], there are 36,770 Cuban health professionals working in every continent. Unlike with this information about Cuba, other Caribbean countries such as Puerto Rico, Haiti, and St. Kitts; and Latin American countries like México, Argentina, Brazil, Ecuador, and Guatemala are developing partnership programs with pharmacy schools in United States to incorporate culturally sensitive concerns within a global pharmacy education and practice framework.

\section{Methods}

A general search was conducted using terms specific to Cuban health care, culture, and education, combined with terms linked to cultural competence, global health, and pharmacy education. Additionally, relevant statements by the Pan American Health Organization (PAHO) and World Health Organization (WHO) were searched. In accordance with the Global Pharmacy Initiative by Federation for International Pharmacy (FIP), pharmacy academics and stakeholders play an essential role in enhancing pharmacy curriculum $[39,40]$. Just like Alsharif [41], one of the authors has served as an external assessor for the pharmacy curricular improvement process and a pharmacy professor over the last 27 years in South America, Africa, and Europe. Moreover, experience of individuals who have studied the Cuban Health System were considered to encourage information referenced in this paper.

\section{Results}

\subsection{General country information}

Located in the Caribbean, Cuba is an archipelago with 11,181, 595 million inhabitants. It covers a surface area of $110,922 \mathrm{~km}^{2}$ which includes the Island of Cuba, Isle of Youth, and more than 1600 islands, islets, and keys [42]. Cuba is characterized by a fantastic diversity of nature, like rolling hills, mountainous areas, savannah, plateaus, 
and valleys. Political and manageable, Cuba is divided into 16 provinces (Camaguey, Ciego de Avila, Cienfuegos, Ciudad de la Habana, Granma, Guantanamo, Holguin, Las Tunas, Matanzas, Pinar del Rio, Sancti Spiritus, Santiago de Cuba, Villa Clara, Artemisa, Mayabeque, and Special Municipality: Isla de la Juventud). Because of its colonization process by Spain first, and later because of slave trade and migrations from Haiti, Cuba has a diverse genetic heritage. The populations of the east of the country have a greater African origin. While most Cubans appear nearer to European ancestry than African, its people lie on the European-African line, comparably to African-descendants from the USA and Barbados. Native American source populations present a less widespread contribution to the Cuban genetic map [43].

Spanish being the official language, most of the population speak it as their well-advanced education. However, Cuban Spanish differs from Castilian Spanish spoken in the Iberian Peninsula due to historic migrations from France, Canary Islands and West Africa. Similarly, there is an anglicization phenomenon in Cuban Spanish [44]. Other languages spoken in the country include Haitian Creole, Lucumi, Galician, and Corsican [45-47]. The Roman Catholic Church and Afro-Cuban religions remain prevalent [48]. Cuba's literacy rate is $99.8 \%$, and health education is part of the obligatory school curriculum [49]. So, all this above description bears upon how to address cultural competence in education.

Since the 1959 Cuban Revolution, the country is marked by continuity of the Communist Party rule. Due to its centralized, state-sponsored economy, Cuba succeeded in building a markedly egalitarian society [50]. Currently, this country is mired in a deep economic crisis, aggravated by the Coronavirus pandemic.

\subsection{Health Issues within the Health Care System.}

After 1959, the Cuban government built a community-based preventive primary care-oriented health care system for equity in the provision of health supplies, including a powerful pharmaceutical industry being prioritized for domestic needs as well as export to Southern Hemisphere nations. At present, there are 103,835 physicians (21,589 family physicians), 5,319 pharmacists, and 84,977 nurses. In 2019, Cuba's gross domestic product (GDP) amounted to around 103.13 billion US\$. GDP decreased $-0.22 \%$ compared to previous years. Cuba spends $11.7 \%$ in the health sector [51].

Prevention is the first principle of the Cuban health system. Many infectious diseases, such as poliomyelitis, diphtheria, pertussis, and rubella, have been eradicated [52]. An exhaustive testing policy controls HIV/AIDS, the country having the lowest HIV prevalence in the Caribbean (0.1\%) in 2007 [53]. The HIV/AIDS program includes wide education effort besides treatment, with anti-retroviral drugs delivered free for all infected patients [54]. Bacterial meningitis showed an incidence of 4.3/100 000 inhabitants from 1998 to 2007 with now a downward trend [55].

A remarkable aspect of the Cuban Health System is comprehensive general medicine or "Medicina General Integral" (MGI). This structure exercises the principles of the Universal Health Strategy promoted by the World Health Organization (WHO) and the Pan American Health Organization (PAHO) [56, 57]. Its programs are concentrated on preventing individuals from developing diseases and treating them as promptly as possible. Thus, Cuba has been successful in the control of daily health concerns. The integration of MGI into the neighbourhood setting and its connection with hospitals and the Medicines Institutes Research allow for population planning and rapid response to emergencies, for example, during hurricanes [58]. As a result, life expectancy at birth for Cuba was 79.5 years, and infant mortality rates decreased from 4.3 per 1000 live births in 2015 to 3.81 in 2019 [59, 60]. The structure of the Cuban National Health System is shown in figure 1. 
A study by Dieci et al. [61] shows relevant comparison of Cuba with other countries, such as Dominican Republic, Costa Rica, and the U.S related to cardiovascular risk factors: International comparison of levels and education gradients. Hypertension understanding in Cuba is similar with that in Costa Rica, considerably lower than in the Dominican Republic, and substantially higher than in the U.S. For both genders, Cubans have hypercholesterolemia incidence that is lower than in Costa Rica and higher than in the U.S. Cuba, like its fellow citizen, must continue to address the rapidly growing non-communicable disease obligation both within and outside of the health care system.

Studies developed by Franco et al. [62] to evaluate the associations between population-wide loss and gain in weight with diabetes prevalence, incidence, and mortality, as well as cardiovascular and cancer mortality trends, in Cuba over a 30-year interval shown a stable incidence between 1.5 per 1000 people and 1.8 per 1000 people during the 1980s decade. Similarly, correlations were established between the decrease in body weight and the decrease in diabetes and coronary heart disease, diabetes mortality increased by $49 \%$ with the weight rebounding. In addition, a slowing in the rate of decrease in mortality from coronary heart disease was observed. Malignant tumors represented the second cause of death in Cuba (24.4\%), in the last 25-year mortality due to Asthma has declined because of preventing therapeutic methods [63].

The Latin American School of Medical Science (ELAM, Spanish acronym) in Cuba is possibly the world's largest medical school with about 10,000 students, all of whom are newcomers [64]. Many students come from Latin American countries, but the enrollment today also includes 91 Americans who were unable to gain entry to U.S. medical schools. In 2010 the ELAM declared the graduation of 34 students from U.S. This statement obliged the institution to achieve accreditation of the Medical Board of California. These contributions additionally complement the effort of the Cuban pharmaceutical industry, which has long been researching medicines for ignored endemic illnesses in developing countries. However, this work of medical education is not perfect, there are reports about the insufficient skills of South African doctors in Cuba related to identity and cultural readjustments necessities for several returning graduates [65].

Recently, a study by González et al. [66] concluded that Cuba considers universal health as one of its most valuable achievements, although it requires a more efficient analysis of reliable and available sources, research, and application of results. Assessing strengths and weaknesses in terms of health economics, updating the sciences, and use of resources and new technologies, as well as deepening lessons learned while facing new challenges. Parallel to that, Cuba has developed a research capacity throughout the health system associated to population mobility, increasing prevalence of chronic diseases, rising health costs, and the need to control communicable diseases in a global context of climate change, among others [67].

\subsection{Cuba's Pharmacy and pharmaceutical services.}

Pharmacy and pharmaceutical services are key elements in the Cuba's organized system of health care, however, there is a recent scarcity of available products related to pharmaceutical services. This makes it difficult to amply measure the impact of pharmaceutical services within the overall system. Currently, Cuba has 2,144 community drugstores constituting its national public network. In 1994 the National Drug Program was implemented to harmonize methodology and regulations related to medicines across the country. Coordinated by the Centre for the Development of Pharmacoepidemiology (CDP), it created the National Pharmacoepidemiology Network in 1996, whose activities concern drug information, continuing education, and the promotion of drug utilization research to improve medicine uses by its populations. Connected to the 15 provincial health boards, through Provincial 
Pharmacovigilance Units within the Provincial Department of Pharmacoepidemiology, which in 1976 set up the National Center for Pharmacoepidemiologic Surveillance with the Coordinating Unit for the Pharmacoepidemiologic Surveillance (CUPS) in 1999. These institutions evaluate and process adverse drug reactions, evaluate the risk-benefit balance of marketed drugs to guarantee safety profiles in drug use [68]. Through its membership in the International Centre for Adverse Drug Reaction monitoring in Uppsala, Sweden, Cuba exchanges information about this topic around the world.

The Cuban drug supply chain is managed by a logistics operator to ensure medicines availability according to patients' needs. This model showed a medium performance level, being a reference of the logistic support to sustain this health system $[69,70]$. Figure 2 shows the structure of the Cuban chain medicines logistic. Many Cuban pharmaceutical products and vaccines are commercialized around the world generating hundreds of millions of dollars annually. Cuba produces $67 \%$ of its own essential medicines, besides recombinant streptokinase [71]. An agreement between The Roswell Park Cancer Institute of Buffalo, New York, and Cuba's Center for Molecular Immunology was assigned to produce a lung cancer vaccine [72].

\subsection{Cuban Pharmacy Education and Organization.}

Cuba has a totally public pharmacy education system. After five years of undergraduate training, the graduates enter at the practical level as BSc. Pharm. Cuban pharmaceutical programs incorporate chemical, physiology and biological sciences education, in addition to practice at the community, hospital, and industry settings. Several year ago, Social Pharmacy disciplines were introduced to yield pharmacists capable to provide pharmacy patientcentered services. Drug information, patient counselling, drug-related problems, and compliance are studied, proposing a 120-h residency to pharmacy practice [73]. In summary, a pharmacy student takes formal clinical pharmacy and pharmaceutical care education (usually from the fourth to the fifth year). Nonetheless, there is not yet a Cuban standard on pharmaceutical care education, being this training a free choice according to the school of pharmacy and geographical health necessities [74].

The National Council on Pharmaceutical Education (NCPE) is responsible for quality pharmacy education with establishing standards and guidance according to practice and education evolution. All schools of pharmacy mandatorily assess their educational results against these standards for accreditation objectives. Standards are established in partnership with academics, consultants, regulators, employers, and other stakeholders. In addition, a final evaluation is carried out by the Council for Accreditation of Higher Education to guarantee adherence to standards [75].

At the community setting Cuban pharmacists deliver counsel about proper pharmaceutical drug uses and overcounter medicines. In addition, they offer advice concerning topics, such as exercise and healthy nutrition. A recent report by Cantluple [76] summarizes the regularities that characterize the Cuban pharmacy sector: "Cuban pharmacists focused on dispensing essential drugs as they negotiated around many drug shortages in the country, pharmacies were described as virtual drug distribution centers but did not offer widespread healthcare services, and pharmacy services in Cuba in primary care are still primarily dispensing-oriented".

\subsection{Diet}

From anthropology and cultural points of view, food is more than nutrition. Relationships between individuals in society are built around food and eating habits, which shape their identity; perceptions of food are directly related to the nature and organization of societies. One's food choices reflect a social reality related to our life and 
perception of the peoples and cultures with which we maintain an identity [77]. A study by Rodríguez-Martín [78] on eating by Cuban adults compared with those of a developed Western country, Italy, showed Cubans reporting higher scores for food thought suppression with reward responsiveness and restrained eating emerging as significant predictors of between-country differences. Similarly, Cubans demonstrated less tendency to food restrictions and a great predisposition to binge eating; eating behaviors in Cubans could be different from those described in European countries, possibly because of Cuba's current history of food shortages.

High consumption of calories, fats and sugars is the main characteristic of the Cuban diet, similarly, consuming whole-grain cereals, fruits, and vegetables is scarce. Food is sold in controlled quantities at government-funded prices since the 1960s. Deficit of micronutrients is a phenomenon present with Cuban people, $30-45 \%$ of infants aged 6 to 23 months, 25-35\% of reproductive-age women, and 24\% of pregnant women are affected for irondeficiency anemia [79]. Disproportionate use of salt in food preparation, minimal intake of dietetic fiber (14g per day), use of reheated oils, minimal consumption of fish, are general characteristics of Cuban eating habits. In short, in Cuba "when you're hungry, eat what is at your fingertips" [80].

High alcohol consumption characterizes the social life of the Cubans. A prospective study by Armas [81] showed that women were current alcohol drinkers, with 15,433 (29\%) men and 3054 (5\%) women drinking at least weekly among 120,623 participants in 1996-2002. All-cause mortality was positively and continuously associated with weekly alcohol consumption; and cancer, vascular diseases were the main causes of death.

\subsection{Safety}

Like other Caribbean islands, Cuba is a safe country. However, the U.S. Department of State's Travel Advisory Level for Cuba at the date of this report's publication remains at Level 2: "Exercise Increased Caution". Travelers must use expanded caution in Cuba caused by discernible and occasionally weakening, damages to members of the U.S. diplomatic community leading to the lessening of embassy staff [82]. Travel to Cuba for people from the states remains banned by statute. The U.S. Department of Treasury's Office of Foreign Assets Control (OFAC) continues to issue general licenses for twelve categories of travel to Cuba. Persons who meet the regulatory conditions of the general license travel are not required to apply for a special license from OFAC.

\subsection{Influence of Spirituality and Traditional Healing on Health.}

Since 1959 the health care system maintains national health care as respecting a human right for all the citizenries. The Cuban health system is the lens through which all the nation's problems are measured, including education, housing, and social security [83]. Thus, resources for maintaining health are free, universal, and accessible for all citizens, thus contributing to the identity of the country. The uniqueness of health care to Cuban nationalism's political and social values remains crucial, though successes in health and medicine do determine national and international aspects of government validity [84].

The life of Cubans is dominated by intense medicalization and a great biomedical hegemony, both individual and collective. However, outside such conventionalisms, there coexist beliefs and therapeutic practices that are beyond the control of the structured Cuban health system, thus, the evil eye (mal de ojo), and gastrointestinal distress syndrome (empacho) are examples of cultural health beliefs [85]. As a result of its ethnic roots, several syncretic religions, and cults rich in ethnobotanical foundation are practiced in Cuba. Vodún (voodoo), Espiritismo (spiritism), and Santería are the consequence of a largely African cultural legacy that also includes Hispanic and Chinese influences [86]. 
By 2005 Cuban government promoted campaigns to resume traditional medicine, and the use of medicinal plants in official therapy, a movement led by the Armed Forces. According to Moret [87], people came to search for medicinal plants as part of their cultural health practices in a spontaneous way inside the savannas and bushes. Now, because of the commercialization of medicinal plants, individuals go to so-called herbalists for convenience. In these establishments, plants are commercialized with little knowledge about their collection and conservation regulations, all of which, according to the authors, could have future difficulties in the access of individuals to ritual resources and medicinal plants. The value of medicinal plants and the commercialization of ethnobotanical knowledge within Afro-Cuban religious activities has increased, amid deficiencies, inequalities, and social movements based on ethnic and religious identities.

\section{Recommendations For Culturally Sensitive Engagement To Cultural Competence Teaching In A Cuban Pharmacy Curriculum}

Tying the above narrative's points of context and description, the application to Cuban pharmacy and curricular reform, thus implies recognizing the social, cultural, economic, and political particularities of Cuba. Likewise, fundamentals related to the treatment of the concepts of culture, multiculturalism and interculturalism specifically in the educational field must be considered.

According to Agüero-Contreras, although the Latin American region and the world may recognize the relevance of the multicultural and intercultural perspective for the deployment of training processes in higher education. In Cuba, the conception of solidarity as politics enters the vision of the process [88]. Theoretical deficits in the social sciences, particularly in the sociology and anthropology of education, regarding the conception and treatment of multiculturalism and interculturalism in the Cuban context have prevented their recognition, and consequently have limited their application in the training process. Even when concrete and important results in the number of graduates are evidenced, the formative process was limited in terms of deep dialogue for cultural socialization to achieve unity within the current diversity.

Implementing cultural competence education in the Cuban pharmacy curriculum should not assume that the knowledge about Cuban culture is known to pharmacy faculties across the island. Differences exist among the provinces on beliefs, rituals, and influences, and the respective prevalence of different religions practiced, along with health and lifestyles [89-92]. Therefore, consideration over spirituality, people's drug information, perceptions related to natural medicine, pharmacognosy, or ethnopharmacology in both pharmacists and patients, must be recognized and studied. From a cultural perspective, looking at the cultural competence education and training implies addressing communicational aspects that govern the pharmacist-patient relationship, or the lack of perception of the pharmacist as a health caregiver. The need to address pharmacy education toward communicative competencies and pharmacist-patient relationship management from the current Cuban society perceptions regarding health and health professionals should be studied in an inter-disciplinary manner. Similarly, aspects related to the eating habits of the Cuban population, their impact on the prevalence of diseases and the relationship of these behaviours with the use of medicines should be studied for the cultural competence education from ethnographic and socio-cultural perspectives.

\section{Conclusion}


Cuba is a culturally rich country with complex and diverse perspectives on health. This article focused on general themes advocating for a holistic, programmatic approach to integrating cultural competence education; it also serves as a call to action for Cuban pharmacy curricular development. Thus, readers must recognize both that, Cuban culture is the result of extremely broad and tedious transculturation processes; at the same time, health and education in Cuba are additionally entwined politically, a condition not always statistically available to be studied, nor scientifically referenced to be verified. Therefore, it is not possible to exhaust the subject in a single inquiry.

The reforms and continuous curricular improvement towards patient-centered care pharmaceutical services should combine the valuable Cuban pedagogical tradition with the study of cultural and religious traditions related to health and the use of medicinal plants. In addition, factors contributing to cultural identity, such as age, sexual orientation, socioeconomic status, beliefs, religion, perceptions about health, life and death, should be considered to implement cultural competence education in a pharmacy curriculum. Being Cuba, a country recognized for its contribution to the training of health professionals for various countries in Latin America and Africa, the relationship with its partners towards consideration of intercultural education experiences in pharmacy education must be considered in cultural competence development.

This article does not present as a mandate; nor is it an exhaustive expose of the varying cultural dynamics, intercultural transitions, and evolution of Cuban perceptions about the health within the viability of the Cuban health system and its pharmaceutical services. This is merely a preliminary point to promote a greater understanding of the relevance of implementing cultural competence in pharmacy education; a Cuban cultural approach to health and pharmacy dynamics portrays the complexity for grasping a Global Pharmacy Education framework.

\section{Abbreviations}

OFAC: U.S. Department of Treasury's Office of Foreign Assets Control; NCPE: National Council on Pharmaceutical Education; CUPS: Coordinating Unit for the Pharmacoepidemiologic Surveillance; CDP: Centre for the Development of Pharmacoepidemiology; ELAM: Latin American School of Medical Science; WHO: World Health Organization; PAHO: Pan American Health Organization; MGI: Medicina General Integral; GDP: Gross domestic product; FIP: Federation for International Pharmacy; IFMSA: International Federation of Medical Students' Associations.

\section{Declarations}

\section{Ethics approval and consent to participate}

Not applicable. This is a theoretical issue of bibliographic review and documentation analysis result of a long collaboration between its authors through studies on pharmacy education around the world.

\section{Consent for publication}

Not applicable.

\section{Availability of data and material}

The data supporting the findings of this study is available and referenced in this manuscript.

\section{Competing interests}

Page $11 / 19$ 
We declare that there are no conflicts of interest. The presented article is an original work, which has not been submitted to other journals.

\section{Funding}

This article has not had any external funding.

\section{Authors' contributions}

All authors contributed to the conceptualization and writing of this monograph. The first draft of the manuscript was written by AM, and JS commented on previous versions of the manuscript. Both authors read and approved the final manuscript.

\section{Acknowledgements}

The authors would like to thank all pharmacy professor and

\section{Author details}

${ }^{1}$ Research professor from the Faculty of Teacher Training and Education of Madrid Autonomous University (Spain). PhD. in Pedagogical Sciences by the University of Granada. Research lines: Interculturality and educative inclusion of ethnical minorities, communicative and social skills in Teacher Training. Recent publications: (Martínez A., Ambrona, T. (2020). “Perspectivas sobre África y los inmigrantes africanos: evaluación en una muestra de estudiantes de magisterio" en Cultura y Educación, 32:4, 649-673. Ex-Chairman - Pharmacy Department University of Oriente, Cuba. ORCID iD: http://orcid.org/0000-0003-1170-6976.

${ }^{2}$ Experienced Independent Researcher with a demonstrated history of working in the international affairs industry. Skilled in Management, Global Health, Healthcare, Healthcare Management, and Strategic Planning. Strong media and communication professional with a Certificate focused in Information Systems For Managed Care and Integrated Health Delivery System Program. from HARVARD UNIVERSITY SCHOOL OF PUBLIC HEALTH. Professor of Health Policy and Administration, School of Public Health.

\section{References}

1. Wiedenmayer, K., Summers, R.S., Mackie, C. A., Gous, A.G, Everard, M., Tromp, D. Developing Pharmacy Practice: A Focus on Patient Care. A 2006 Edition Handbook. World Health Organization and International Pharmaceutical Federation.

https://www.fip.org/files/fip/publications/DevelopingPharmacyPractice/DevelopingPharmacyPracticeEN.pdf. Accessed 27 Mar 2021.

2. World Health Organization. Transforming and scaling up health professionals' education and training: World Health Organization Guidelines 2013. The World Health Organization. Available at: Available at: https://apps.who.int/iris/bitstream/handle/10665/93635/9789241506502_eng.pdf?sequence=1. Accessed 27 Mar 2021.

3. FIP (2010). Pharmacy Education Taskforce. A Global Competency Framework for Services Provided by Pharmacy Workforce. Available at: Available at: https://fip.org/files/fip/PharmacyEducation/GbCF\%20booklet.pdf. Accessed 27 Mar 2021. 
4. Anderson, C., Bates, I., \& Brock, T. Needs-based education in the context of globalization. Am J Pharm Educ. 2012; 76, 4, Article 56. https://doi.org/10.5688/ajpe76456

5. Saleh, O.S., Ahmad-Hassali, M.A., Abduelkarem, A.R. Social pharmacy courses are often neglected in the developing world. Am J Pharm Educ. 2011;75(4):65b. https://doi.org/10.5688/ajpe75465b

6. Izham, M., Mohamed, I., Albert, I, Zaheer-Ud-Din, B. Social and Administrative Aspects of Pharmacy in Lowand Middle-Income Countries: Present Challenges and Future Solutions: Elsevier Inc, p. 48. 2018. https://doi.org/10.1016/C2016-0-00792-1.

7. Abrika, O.S., Hassali, M.A., Abduelkarem, A. R. Social pharmacy courses are often neglected in the developing world. Am J Pharm Educ. 2011; 75(4):65b. https://doi.org/ 10.5688/ajpe75465b.

8. Toklu, H. Z. Pharmaceutical Education vs. Pharmacy Practice: Do We Really Teach What They Need for Practicing?, J Pharma Care Health Sys. 2015; 2: e134. https://doi.org/10.4172/2376-0419.S3.e001.

9. Olsen, A. A., Minshew, L. M., Morbitzer, K. A., Brock, T. P., \& McLaughlin, J. E. Emerging Innovations and Professional Skills Needed Within Pharmacy Curricula. Journal of medical education and curricular development. 2020; 7: 2382120520943597. https://doi.org/10.1177/2382120520943597

10. Davis M. The "Culture” in Cultural Competence. In: Frawley J., Russell G., Sherwood J. (eds) Cultural Competence and the Higher Education Sector. Springer, Singapore. 2020. https://doi.org/10.1007/978-981-155362-2_2

11. Cross, T. L., Bazron, B. J., Dennis, K. W. \& Isaacs, M. R. (1989). Towards a culturally competent system of care: A monograph on effective services for minority children who are severely emotionally disturbed. Washington, DC: Child and Adolescent Service System Program Technical Assistance Center, Georgetown University Child Development Center.

12. Shaya, F. T., \& Gbarayor, C. M. The case for cultural competence in health professions education. American journal of pharmaceutical education. 2007; 70(6): 124. https://doi.org/10.5688/aj7006124

13. Singer, F., Samihaian, F., Holbrook, J., \& Crisan, A. Developing a Competence-based Curriculum for the 21st Century: The Case of Kuwait. Procedia - Social and Behavioral Sciences. 2014.

https://doi.org/128

. 10.1016/j.sbspro.2014; 03.191.

14. Gilbert, J. Competency Based Education and Training. Bristol: The Falmer Press. 1989.

15. Grant, G., Elbow, P., Ewens, T., Gamson, Z., Kohli, W., Neumann, W., Olesen, V. and Riesman, D. On Competence. A critical analysis of competence-based reforms in higher education. San Francisco: Jossey-Bass. 1979.

16. Wang, T. Competence for Students' Future: Curriculum Change and Policy Redesign in China. ECNU Review of Education. 2019; 2(2): 234-245. https://doi.org/10.1177/2096531119850905

17. Torres, X. Organizacion de los contenidos y relevancia cultural. Cuadernos de pedagogía 2014; 447: 50-53.

18. Sánchez AM Bachelor of Pharmacy Degree in Cuba: New Educational Challenges. Am J Pharm Educ. 2011; 75(1):3-5 Article 13.

19. Proenza, J., \& Mateo, J. La formación de competencias profesionales para la educación del tiempo libre en la formación inicial de los profesionales de la cultura física y el deporteLecturas: Educación Física y Deportes, Revista Digital. Buenos Aires. 2011, 16, 163. Available at: http://www.efdeportes.com/efd163/competenciasprofesionales-para-la-educacion-del-tiempo-libre.htm Accessed 27 Mar 2021.

20. Nair, L., \& Adetayo, O. A. Cultural Competence and Ethnic Diversity in Healthcare. Plastic and reconstructive surgery. Global open. 2019; 7(5): e2219. https://doi.org/10.1097/GOX.0000000000002219 
21. Tan, N., \& Li, S. Multiculturalism in Healthcare: A Review of Current Research into Diversity Found in the Healthcare Professional Population and the Patient Population. International Journal of Medical Students. 2016; 4(3): 112-119. https://doi.org/10.5195/ijms.2016.163

22. Shepherd, S.M., Willis-Esqueda, C., Newton, D. The challenge of cultural competence in the workplace: perspectives of healthcare providers. BMC Health Serv Res. 2019; 19: 135. https://doi.org/10.1186/s12913019-3959-7

23. IFMSA. Policy Document Cultural Competence in Healthcare. Proposed by IFMSA-Pakistan and CroMSIC Crotia Presented to the IFMSA General Assembly March Meeting 2020, in Rwanda. 2020. Available at: https://ifmsa.org Accessed 27 Mar 2021.

24. Accreditation Council for Pharmacy Education. Guidance for the Accreditation Standards and Key Elements for the Professional Program in Pharmacy Leading to the Doctor of Pharmacy Degree ("Guidance for Standards 2016"). 2016. Available at: https://www.acpeaccredit Accessed 27 Mar 2021.

25. Medina, M. S., Plaza, C.M., Stowe, C.D. Center for the Advancement of Pharmacy Education 2013 educational outcomes. Am J Pharm Educ. 2013; 77 (8): Article 162.

26. Armbruster, A., Henson, B., \& Alsharif, N. A Call to Action for a Programmatic Approach to Cultural Competency in Pharmacy Education. Am J Pharm Educ. 2021; 85(6): 8412, https://doi.org/10.5688/ajpe8412

27. Patel, I., Gadwal, T., Shrestha, S., Khieri, S., Miller, M. K., Guy, J. W., Chang, J., \& Johnson, M. Cultural competency education in pharmacy curricula-need and implementation. Indian Journal of Pharmacy Practice. 2020; 13 (2): 97-112. https://doi.org/10.5530/ijopp.13.2.16

28. Assemi, M., Cullander, C, \& Hudmon, K. S. Implementation and evaluation of cultural competency training for pharmacy students. Ann Pharmacother. 2004; 38, 5: 781-786. https://doi.org/10.1345/aph.1D402

29. Durand, Ch., Abel, Ch., Silva, M., Desilets, A. An elective course in cultural competence, Currents in Pharmacy Teaching and Learning. 2012; 4(2): 102-108. https://doi.org/10.1016/j.cptl.2012.01.002.

30. O’Connell, M.B., Korner, E.J., Rickles,N. M., Sias, J. J. American College of Clinical Pharmacy White Paper. Cultural Competence in Health Care and Its Implications for Pharmacy, Part 1. Overview of Key Concepts in Multicultural Health Care. Pharmacotherapy. 2007; 27(7):1062-1079.

https://doi.org/10.1592/phco.27.7.1062

31. Poirier, T.I., Butler, L.M., Devraj, R., Gupchup, G.V., Santello, C., Lynch, J. C. A cultural competency course for pharmacy students. Am J Pharm Educ. 2009; 73(5): Article 81. https://doi.org/10.5688/aj730581

32. Bazaldua, O.V., Sias, J. Cultural Competence: A Pharmacy Perspective. J Phar Pract. 2004, 17(3),160-166. doi:10.1177/0897190004264812

33. Haack, S. Engaging pharmacy students with diverse patient populations to improve cultural competence. American journal of pharmaceutical education. 2008; 72(5): 124. https://doi.org/10.5688/aj7205124

34. Minshew, L., Lee, D., White, C., McClurg, M., \& McLaughlin, J. Cultural Intelligence in Pharmacy Education: Understanding Student Experiences, Am J Pharm Educ. 2021: 8580. https://doi.org/10.5688/ajpe8580

35. Martínez-Sánchez, A. A New Approach to Health Services and Pharmacy in Cuba. Pharmacotherapy. $2015 ; 35$ (12): 1100-1108. DOI: 1100-1108. 10.1002/phar.1663.

36. Abrons, J.P., Andreas, E., Jolly, O., Parisi-Mercado, M., Daly, A., \& Carr, I. Cultural Sensitivity and Global Pharmacy Engagement in the Caribbean: Dominica, Jamaica, Puerto Rico, and St. Kitts. Am J Pharm Educ. 2019; 83(4), 7219. https://doi.org/10.5688/ajpe7219. 
37. Haack, S.L., Mazar, I., Carter, E.M., Addo-Atuah, J., Ryan, M., Salazar, L.L., González, L.R., Barrera, A.L. Cultural Sensitivity and Global Pharmacy Engagement in Latin America: Argentina, Brazil, Ecuador, Guatemala, and Mexico. Am J Pharm Educ. 2019; 83(4):7218. doi: 10.5688/ajpe7218.

38. Gorry, C. Cuban Health Cooperation Turns 45. MEDICC Review. 2008; 10(3): 44-47.

39. Anderson, C., Bates, I., Beck, D. FIP roundtable consultation on pharmacy education: developing a global vision and action plan. Intl Pharm J. 2006; 20:12-13. https://doi.org/10.5688/aj7206127

40. Anderson, C., Bates, I., \& Beck, D. Action! update on the global pharmacy education consultation. Intl Pharm J. 2008; 22: 6-8. https://doi.org/10.5688/aj7206127

41. Alsharif, N. Globalization of pharmacy education: what is needed?. Am J Pharm Educ. 2012; 76,5: 77. https://doi.org/10.5688/ajpe76577

42. Anuario Estadistico de Cuba. Public Health Assistance. Edition 2020. Available at: http://www.onei.gob.cu/node/16275 Accessed 27 Mar 2021.

43. Fortes-Lima, C., Bybjerg-Grauholm, J., \& Marin-Padrón, L.C. Exploring Cuba's population structure and demographic history using genome-wide data. Sci Rep. 2018; 8: 11422. https://doi.org/10.1038/s41598-01829851-3

44. Sánchez, J. The Anglicization of Cuban Spanish: A Historical Account. Analele Universitatii din Craiova - Seria Stiinte Filologice. 2017; 39: 186-201.

45. Valdés, S. The lexicographic studies of Fernando Ortiz Fernández. Journal of Ethnographic Theory. 2021; 11(1): 141-152. https://doi.org/10.1086/714378

46. Viddal, G. Vodú Chic: Cuba's Haitian Heritage, the Folkloric Imaginary, and the State. Doctoral dissertation, Harvard University. 2014.

47. Villepastour, A. The Cuban Lexicon Lucumí and African Language Yorùbá: Musical and Historical Connections. In: Brunn S., Kehrein R. (eds) Handbook of the Changing World Language Map. Springer, Cham. 2020. https://doi.org/10.1007/978-3-030-02438-3_183

48. Crahan, M. (1979). Salvation through Christ or Marx: Religion in Revolutionary Cuba. Journal of Interamerican Studies and World Affairs. 1979; 21(1): 156-184. https://doi.org/10.2307/165694

49. Murtala, Y., Badanguida, L., Isman, I., Halilu, A. Comparative study of the state of literacy in Nigeria and Cuba. Eur Sci J. 2013; 9(19):1857-7431.

50. Mesa-Lago, C., \& Pérez-López, J. F. Cuba's Aborted Reform: Socioeconomic Effects, International Comparisons and Transition Policies, Gainesville: University Press of Florida. 2005.

51. OCDE. Base Mundial de Gasto en Salud de la OMS. Estadísticas de Salud de la OCDE 2019 correspondientes a Brasil, Chile, Colombia, Costa Rica y México. 2020. Available at: https://stat.link/73bl8k Accessed 27 Mar 2021.

52. Mas, P. Eradication of poliomyelitis in Cuba: a historical perspective. Bull World Health Organ. 1999; 77:6817.

53. de Arazoza, H., Joanes, J., Lounes, R., Legeai, C., Clémençon, S., Pérez, J., \& Auvert, B. The HIV/AIDS epidemic in Cuba: description and tentative explanation of its low HIV prevalence. BMC infectious diseases. 2007; 7: 130. https://doi.org/10.1186/1471-2334-7-130

54. Zaldívar, G., \& Esquenazi, A. Cuban Health System: a Look to its Financing System. Economía y Desarrollo. 2019; 162(2): e14. 
55. Pérez, A.E., Dickinson, F.O. \& Rodríguez, M. Community acquired bacterial meningitis in Cuba: a follow up of a decade. BMC Infect Dis. 2010; 10: 130. https://doi.org/10.1186/1471-2334-10-130

56. Evans, D., Hsu, J., Boerma,T. Universal health coverage and universal access [Editorial] ; Bull World Health Organ. 2013. Available at: http://www.who.int/bulletin/volumes/91/8/13125450.pdf. Accessed 27 Mar 2021.

57. Organización Panamericana de la Salud (OPS). (2014). CD53.R14: estrategia para el acceso universal a la salud y la cobertura universal de salud. Washington D.C.: OPS. Available at: http://iris.paho.org/xmlui/handle/123456789/7652?show=full. Accessed 27 Mar 2021.

58. Whiteford, L.M., \& Branch, L.G. Primary health care in Cuba: the other revolution. Lanham: Rowman \& Littlefield Publishers Inc.2008.

59. Berdine, G., Geloso, V., \& Powell, B. Cuban infant mortality and longevity: health care or repression?, Health Policy and Planning. 2018; 33(6): 755-757, https://doi.org/10.1093/heapol/czy033

60. World Health Organization. Cuba Statistic. 2019. http://www.who.int/countries/cub/en/.

61. Dieci, M., Llibre-Rodriguez, J.J., Acosta, D., \& Dow, W.H. Cuba's cardiovascular risk factors: International comparison of levels and education gradients. PLOS ONE. 2021; 16(3): e0247831. https://doi.org/10.1371/journal.pone.0247831

62. Franco, M., Bilal, S., Orduñez. P. Population-wide weight loss and regain in relation to diabetes burden and cardiovascular mortality in Cuba 1980-2010: repeated cross-sectional surveys and ecological comparison of secular trends. BrMed J. 2013; 46: 1515. https://doi.org/10.1136/bmj.f 1515

63. Landrove-Rodríguez, O., Morejón-Giraldoni, A., Venero-Fernández, S., Suárez-Medina, R., Almaguer-López, M., Pallarols-Mariño, E. Enfermedades no transmisibles: factores de riesgo y acciones para su prevención y control en Cuba. Rev Panam Salud Publica. 2018; 42: e23. https://doi.org/10.26633/RPSP.2018.23

64. Afra, J. The Latin American School of Medicine (Elam): Admissions, Academics and Attitudes. International Journal of Cuban Studies. 2017; 9(1): 142-154. https://doi.org/10.13169/intejcubastud.9.1.0142

65. Squires, N., Colville, S.E., Chalkidou, K. Medical training for universal health coverage: a review of Cuba-South Africa collaboration. Hum Resour Health. 2020; 18: 12. https://doi.org/10.1186/s12960-020-0450-9

66. González, A., López, R. G., Muñiz, M. Á., Ledo, M., Lugo, N., \& Santiesteban, M. V. Economic considerations on Cuban public health and its relationship with universal. Pan American Journal of Public Health. 2018; 42 : e28. https://doi.org/10.26633/RPSP.2018.28

67. Lage, A. Science and Challenges for Cuban Public Health in the 21st Century. MEDICC Review. 2019; 21(4): 714.

68. Ministerio de Salud Pública. Programa Nacional de Medicamentos. La Habana; Cuba. 1998.

69. López-Joy,M.I., T, Gómez-Acosta,A.N. Neira-Mugercia,J.A. Acevedo-Suárez,C.Peña-García,andA.J. AcevedoUrquiaga. Medicines value chain management level in Cuban health system, Ing Univ. 2020; 24. https://doi.org/10.11144/Javeriana.iyu24.mvcm

70. López-Martínez, I. Cadena de suministro de medicamentos”, Nueva Empresa, 7. (Web reference: Matrícula de la Escuela Latinoamericana de Medicina en Cuba llega a los 10000 estudiantes. 2011. Available at: http://www.cubadebate.cu/noticias/2010/03/16/matricula-de-la-escuelalatinoamericana-de-medicina-encuba-llega-a-los-10-000-estudiantes. Accessed 27 Mar 2021.

71. Giraldo, G. Three-Pronged Innovation to Improve Care for Acute Myocardial Infarction Patients in Cuba. MEDICC Review. 2010;12(3):11-6. 
72. González, G., Lage, A., Crombet, T., Rodríguez, G., García, B, Cuevas, A., Viña, L., Arteaga, N., \& Neninger, E. CIMAvax-EGF: A novel therapeutic vaccine for advanced lung cancer. Biotecnología Aplicada. 2009; 26(4): 345-348.

73. Sedeño, C., Pichardo, M., Mateu, L. Observatorio farmacéutico: conocer y transformar. Rev de la OFIL. 2005; 15(4): 33-8.

74. Suárez, Y. Nuevo plan de estudio para la Licenciatura en Ciencias Farmacéuticas. Rev Cuba de Farm. 2018; 51: 2. http://www.revfarmacia.sld.cu/ index.php/far/article/view/223/115.

75. Horruitiner, P. El modelo de acreditación de carreras de la educación superior cubana. Revista Iberoamericana de Educación (serial on the Internet). 2007; 44(2): 1-13.

76. Cantlupe, A. Behind Cuba's Healthcare Curtain. An AACP delegation got a peek at how the past and future come together to comprise Cuba's healthcare infrastructure. 2021. Available at: https://www.aacp.org/article/behind-cubas-healthcare-curtain Accessed 27 Mar 2021.

77. Paponnet-Cantat, C. The Joy of Eating: Food and Identity in Contemporary Cuba. Caribbean Quarterly. 2003; 49(3): 11-29. Available at: http://www.jstor.org/stable/40654408 Accessed 27 Mar 2021.

78. Rodríguez-Martín, B. C., Innamorati, M., Imperatori, C., Fabbricatore, M., Harnic, D., Janiri, L., \& Rivas-Suárez, S. R. Eating Behaviors in Cuban Adults: Results from an Exploratory Transcultural Study. Frontiers in psychology. 2016; 7: 1455. https://doi.org/10.3389/fpsyg.2016.01455

79. Pérez, R. The Public Health Sector and Nutrition in Cuba. MEDICC Review. 2009; 11, 4: 6-8. Available at: https://www.redalyc.org/articulo.oa?id=437542071003 Accessed 27 Mar 2021.

80. Porrata, C. Cubans' Deadly Diet: A Wakeup Call. MEDICC Review. 2008; 10(2): 52. https://doi.org/10.1016/j.eclinm.2020.100692.

81. Armas, N.B. Alcohol consumption and cause-specific mortality in Cuba: prospective study of 120623 adults. EClinicalMedicine. 2021; 33:100692.

82. Travel Advisory. Cuba 2020 Crime \& Safety Report. 2020. Available at: https://www.osac.gov/Country/Cuba/Content/Detail/Report/66451c0e-dfaa-4499-ab83-180feb5740e7. Accessed 27 Mar 2021.

83. All Answers Ltd. (November 2018). Health Systems Paper: Health System in Cuba. Available at: https://nursinganswers.net/essays/health-systems-paper-health-system-in-cuba.php?vref=1 Accessed 27 Mar 2021.

84. Candace, J. Health as Culture and Nationalism in Cuba, Canadian Journal of Latin American and Caribbean Studies / Revue canadienne des études latino-américaines et caraïbes. 2006; 31(61): 91-113, https://doi.org/10.1080/08263663.2006.10816891

85. Campos-Navarro, R. El empacho en Cuba: Aproximación histórica documental desde 1821 hasta 2009. Cuicuilco. 2009; 16(46): 71-96.

86. Alvarado, J. A., La Rosa Corzo, G., Guanche Pérez, J., \& Valdés Pérez, S. La Ruta del Esclavo. Ediciones Geo: Havana. 1998.

87. Moret, E. Afro-Cuban Religion, Ethnobotany and Healthcare in the Context of Global Political and Economic Change. Bulletin of Latin American Research. 2008; 27, 3: 333-350.

88. Agüero -Conteras, F; Urquiza-García, C. Multiculture and interculturality: implications of a lack in education. Educ. Pesqui. 2016; 42, 2: 459-475. https://doi.org/10.1590/S1517-9702201606146327 
89. Basil, A. Religión y política en cuba. Argucias de las identidades religiosas y sus dimensiones políticas. Mitológicas. 2001; XVI,1: 115-133.

90. Betancourt, G., \& Rivero, J. Limitación del esfuerzo terapéutico: aspectos religiosos y culturales. Humanidades Médicas. 2015; 15(1): 145-162.

91. Íñiguez, L. Precedencias y efectos de los procesos de la década del 90 en las desigualdades sociales en Cuba. Anales de Geografía de la Univ. Complutense. 2002; 22: 157-185

92. Perera, A., \& Pérez Cruz, O. Crisis social y reavivamiento religioso: Una mirada desde lo sociocultural. Cuicuilco. 2009; 16(46): 135-157.

\section{Figures}

\section{Medical}

Institutes

(12)

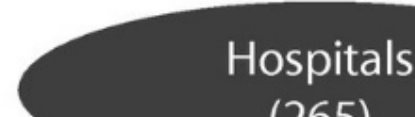

(265)

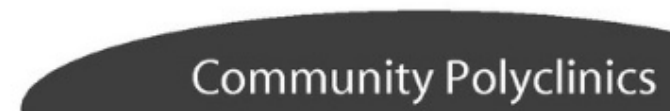

(488)

\section{Basic Work Teams}

\section{Family Doctor-and-Nurse Team}

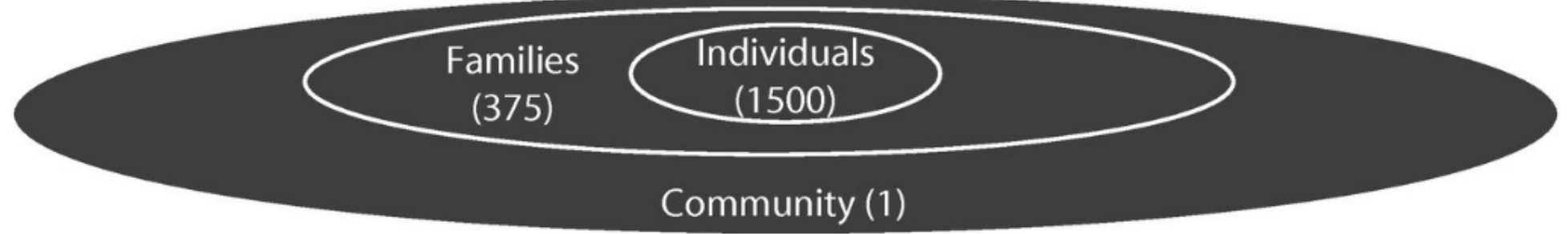

Figure 1

The Cuban Health Pyramid (Source: Keck, W and Reed, G. (2012). The Curious Case of Cuba. American Journal of Public Health, 102 (8), e13-e22. https://doi.org/10.2105/AJPH.2012.300822) 


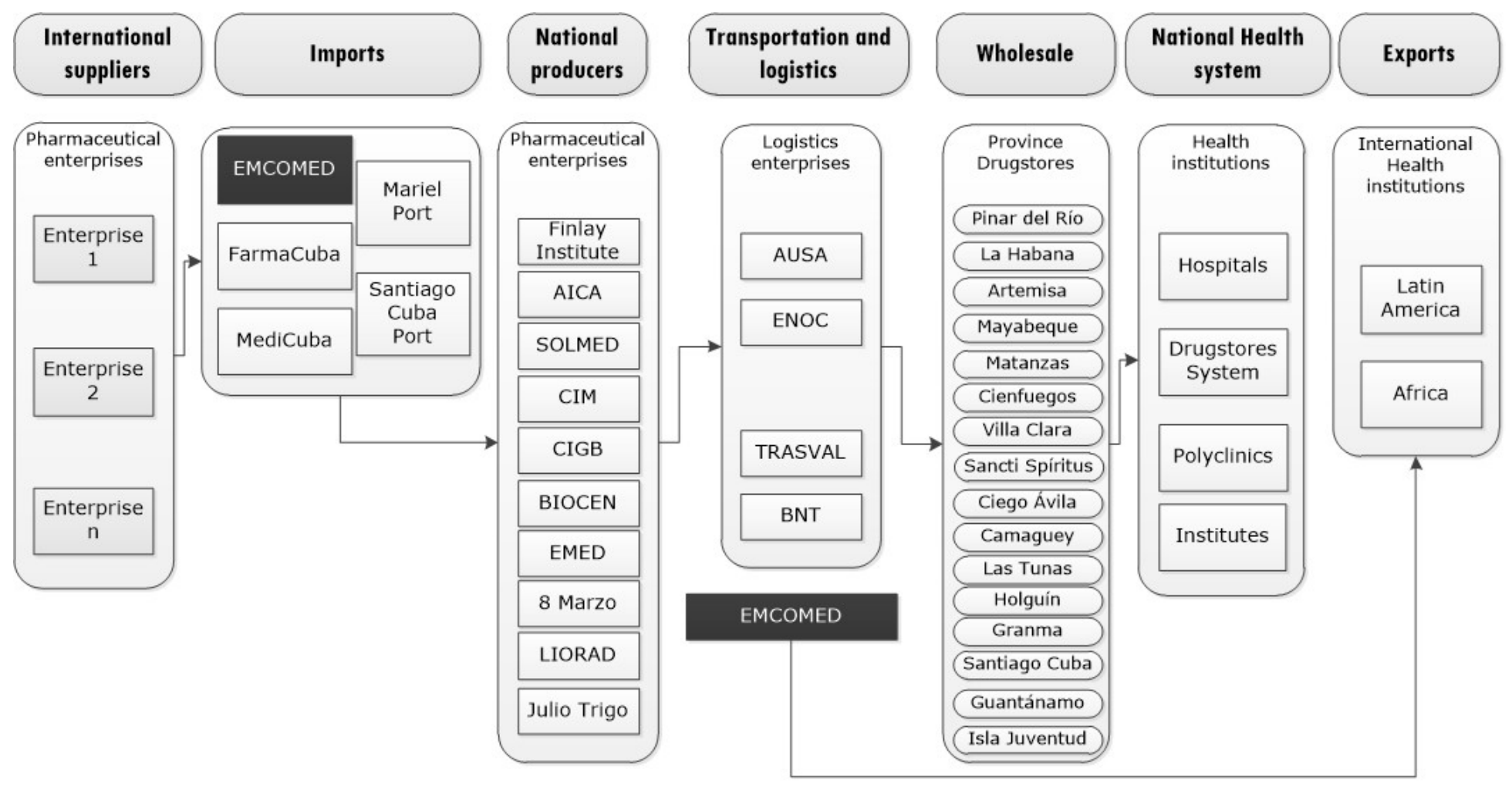

EMCOMED

BioCubaFarma

Figure 2

Medicine supply chain for the Cuban health system. Source: López-Joy, M.I., T, Gómez-Acosta, A.N. NeiraMugercia, J.A. Acevedo-Suárez, C. Peña-García, and A.J. Acevedo-Urquiaga. (2020). Medicines value chain management level in Cuban health system, Ing.Univ.,24. https://doi.org/10.11144/Javeriana.iyu24.mvcm EMCOMED - specialized logistics operator for the pharmaceutical sector. 